\title{
PENYALAHGUNAAN KEADAAN SEBAGAI DASAR PEMBATALAN PERJANJIAN
}

\author{
Bernadeta Resti Nurhayati \\ Fakultas Hukum dan Komunikasi, Universitas Katolik Soegijapranata \\ e-mail: resti@unika.ac.id
}

\begin{abstract}
ABSTRAK
Kesepakatan antara para pihak merupakan ruhnya perjanjian. Namun dalam praktik, kesepakatan perjanjian tidak selalu diberikan secara bebas. Cukup banyak perjanjian yang memiliki cacat kehendak karena dibuat atas dasar keterpaksaan, ancaman, atau ketidaktahuan para pihak. Kecacatan pada kesepakatan bisa terjadi karena adanya dwang, dwaling, bedrog maupun karena terjadi penyalahgunaan keadaan. Perjanjian yang di dalamnya terkandung unsur penyalahgunaan keadaan berpotensi untuk digugat di pengadilan ketika salah satu pihak menyadari bahwa kesepakatan yang diberikan pada saat penandatanganan perjanjian bercacat. Metode penelitian yang digunakan dalam kajian ini adalah yuridis normatif, dengan pendekatan peraturan perundang-undangan (statute approach) dan pendekatan kasus (case approach). Berdasarkan kajian yang dilakukan, ditemukan bahwa dalam perkara gugatan penyalahgunaan keadaan, tidak selalu gugatan dimenangkan oleh pihak yang mendalilkan telah mengalami penyalahgunaan keadaan. Namun cukup banyak gugatan berdasarkan penyalahgunaan keadaan yang dimenangkan oleh pihak penggugat. Ini dapat diartikan bahwa dalil penyalahgunaan keadaan menjadi salah satu bentuk perlindungan hukum bagi pihak yang dirugikan karena masuk dalam sebuah perjanjian yang tidak berimbang.
\end{abstract}

Kata kunci: perjanjian, cacat kehendak, penyalahgunaan keadaan.

\begin{abstract}
Consent between corresponding parties serves as agreement's essentials. However, practically what we know as deals are not independently settled. There are deformed agreements that fall because of assimetric information, obliged opinion, or even real menace. They are commonly caused by misguidance (dwang), wrong/errorneous/blunder (dwaling), bedrog deception (bedrog), and undue influence (misbruik van omstandigheden). An agreement carrying situational abuse might be at greater likelihood of facing future claim, whenever one party realise any defective substance. This paper employs normative-juridical method with statute and case study approach. Researcher finds most cases are leaning towards the lawsuit. In fact data suggests opposite result are still less likely, so protection should be in place. Researcher sees undue influnce as a potential dip which could require legal shelter to protect involved parties in deformed agreements cases.
\end{abstract}

Key words: contract, non independently settled, undue influence.

\section{PENDAHULUAN}

Hukum Perdata adalah hukum antar perorangan yang mengatur hak dan kewajiban perorangan yang satu terhadap yang lain di dalam hubungan keluarga dan di dalam pergaulan masyarakat. Hukum dalam 
hubungan keluarga melahirkan dua bidang hukum, yaitu hukum tentang orang dan hukum keluarga, sedangkan hukum dalam pergaulan masyarakat melahirkan hukum benda dan perikatan (Mertokusumo, 2010: 169). Hubungan yang terjadi dalam pergaulan masyarakat menyebabkan timbulnya berbagai bentuk hubungan hukum antar orang, khususnya khususnya dalam bidang hukum perikatan, dimana mayoritas hubungan perikatan yang terjadi antar orang bersumberkan pada perjanjian.

Hukum perjanjian merupakan bidang hukum yang bersifat terbuka, sehingga memungkinkan berkembang sangat cepat sesuai dengan perkembangan masyarakat. Sifat terbuka dalam bidang hukum perjanjian memberikan kebebasan bagi masyarakat untuk membuat perjanjian dalam segala bidang sesuai dengan kebutuhan masyarakat. Perkembangan ini baik mengenai bentuk, isi, maupun cara menyampaikan kesepakatan. Hal inilah yang menyebabkan bidang hukum perjanjian berkembang pesat. Demikian pula semakin luas bidang yang dijangkau oleh hukum perjanjian. Pembatasan terhadap kebebasan ini hanya sepanjang perjanjian tersebut tidak bertentangan dengan peraturan perundang-undangan yang berlaku, kesusilaan, serta ketertiban umum.

Meskipun bidang hukum perjanjian berkembang pesat, namun terdapat hal-hal yang mendasar dari sebuah perjanjian, seperti: syarat sahnya perjanjian dan asas-asas perjanjian masih mengikuti doktrin-doktrin lama. Pasal 1320 KUHPerdata yang mengatur mengenai syarat sahnya perjanjian misalnya menjadi hukum pemaksa (dwingend recht), artinya ketentuan tentang syarat sahnya perjanjian bersifat mengikat, wajib untuk dipenuhi bagi setiap orang yang mengikat perjanjian.
Pasal 1320 KUHPerdata menetapkan bahwa perjanjian sah apabila memenuhi syarat sebagai berikut:

1. Sepakat mereka yang mengikatkan dirinya;

2. Kecakapan untuk membuat suatu perikatan;

3. Suatu hal tertentu;

4. Suatu sebab yang halal.

Pada dasarnya, sepakat mereka yang mengikatkan diri adalah sepakat yang bulat, sepakat yang tak bercacat, sepakat yang diberikan secara bebas. Kehendak para pihak haruslah kehendak yang murni, bebas, dan dinyatakan dengan suasana yang bebas pula (J. Satrio, 1992: 187).

Istilah sepakat, secara implisit menandakan bahwa hal itu dibangun paling tidak oleh dua pihak. Berarti masing-masing pihak untuk dapat mencapai sepakat harus mempertemukan kehendaknya masingmasing yang diungkapkan melalui pernyataan. "For there to be a contract, they must of course be a meeting of the minds'. That is, both parties must be agreeing to a deal". Sepakat tidak lain merupakan perjumpaan antara penawaran (offer/offerte) dengan akseptasi (acceptance) acceptatie). Apabila satu pihak melakukan penawaran dan kemudian diakseptasi oleh pihak lain, maka lahirlah kontrak (Isnaeni, 2013: 5). Adapun J. Satrio menyebut bahwa sepakat sebenarnya merupakan pertemuan antara dua kehendak, dimana kehendak orang yang satu saling mengisi dengan apa yang dikehendaki pihak lain (J. Satrio, 1992: 128). Dari paparan tersebut jelas bahwa kesepakatan merupakan momen yang sangat penting untuk terbentuknya perjanjian.

Di Inggris, yang merupakan negara dengan sistem Anglosaxon pun dikenal bahwa kesepakatan dalam perjanjian haruslah diberikan secara bebas dengan pemahaman secara penuh. Salmond menyebutkan bahwa "...freely and with full knowledge consented to 
it" (1947: 351). Dan "Essential error is that which is of such a nature as to prevent the existence of any real, consent, and therefore any real agreement" (1947: 357). Dengan demikian, secara umum dapat dikatakan bahwa dalam berbagai sistem hukum, tidak dipenuhinya kebebasan dalam menyatakan kehendak, merupakan salah satu alasan untuk menyatakan bahwa kesepakatan dalam perjanjian tersebut cacat.

Dalam sistem KUHPerdata, dalam doktrin serta jurisprudensi umum di Indonesia, terdapat tiga kelompok yang menyebabkan cacat dalam kehendak, yakni:

1. kesesatan (dwaling);

2. paksaan (dwang);

3. penipuan (bedrog).

Tetapi dalam perkembangan lebih lanjut, hukum perjanjian menerima penyalahgunaan keadaan sebagai unsur yang menyebabkan cacat kehendak.

Dalam praktik peradilan di Indonesia, terdapat berbagai variasi putusan pengadilan, baik dalam pengadilan tingkat pertama maupun dalam tingkat yang lebih tinggi dalam perkara gugatan pembatalan perjanjian berdasarkan unsur penyalahgunaan keadaan. Berdasarkan hasil kajian, dalam praktik tidak semua gugatan atas dasar terjadinya penyalahgunaan keadaan dikabulkan oleh hakim. Oleh karena itu penulis tertarik untuk mengkaji unsur penyalahgunaan keadaan sebagai alasan untuk mengajukan gugatan pembatalan perjanjian.

Tulisan ini bukanlah tulisan pertama yang mengupas perihal unsur penyalahgunaan keadaan perjanjian. Namun terdapat kebaruan dalam tulisan ini, karena mengupas berdasarkan yurisprudensi yang ada serta perbandingan dengan sistem dalam Nieuw Burgerlijk Wetboek (BW Baru).

\section{PERUMUSAN MASALAH}

Berdasarkan uraian tersebut di atas dapat dirumuskan uraian permasalahan sebagai berikut: Bagaimanakah unsur penyalahgunaan keadaan digunakan sebagai dasar pembatalan perjanjian.

\section{METODE PENELITIAN}

Metode penelitian yang digunakan dalam kajian ini adalah yuridis normatif, dengan pendekatan peraturan perundang-undangan (statute approach) dan pendekatan kasus (case approach). Pendekatan undang-undang dilakukan dengan menelaah semua undangundang dan regulasi yang bersangkut paut dengan isu hukum yang dibahas. Pendekatan ini akan membuka kesempatan bagi peneliti untuk mempelajari adakah konsistensi dan kesesuaian antara suatu undang-undang dengan undang-undang lainnya, atau antara undang-undang dengan UUD atau antara regulasi dengan undang-undang (Marzuki, 2006: 93). Sedangkan pendekatan kasus dilakukan dengan cara melakukan telaah terhadap kasus-kasus yang berkaitan dengan isu yang dihadapi (Marzuki, 2006: 94), khususnya soal penyalahgunaan keadaan dalam perjanjian.

\section{PEMBAHASAN}

\section{Pengertian Perjanjian}

Perjanjian menurut teori klasik adalah suatu perbuatan hukum yang bersisi dua (een tweezijdige overeenkomst) yang didasarkan atas kata sepakat untuk menimbulkan akibat hukum. Sisi pertama adalah penawaran (offer, aanbod) sedangkan sisi kedua berisi penerimaan (acceptance, aanvaarding). Kedua sisi tersebut merupakan satu kesatuan, sehingga disebut sebagai suatu perbuatan hukum. Namun, pandangan klasik tersebut menurut Mertokusumo kurang tepat. Penawaran dan penerimaan masing-masing 
merupakan dua perbuatan hukum yang masing-masing bersisi satu. Dengan demikian perjanjian tidaklah merupakan satu perbuatan hukum, akan tetapi merupakan hubungan hukum antara dua orang yang bersepakat untuk menimbulkan akibat hukum (Mertokusumo, 2010: 153).

Kiranya tepat pandangan tersebut, karena pada kedua belah pihak atau bahkan pada perjanjian multi pihak, pada tiap pihak mempunyai hak yang sama memberikan kesepakatan, untuk mengubah isi perjanjian, untuk menuntut apabila prestasi yang dijanjikan tidak dipenuhi, atau timbul hal yang merugikan pihaknya.

\section{Syarat Sahnya Perjanjian}

Telah disebutkan di atas, bahwa syarat sahnya perjanjian diatur dalam Pasal 1320 KUHPerdata, yang menyebutkan bahwa perjanjian sah apabila memenuhi empat syarat: (1) Kesepakatan mereka yang membuat perjanjian; (2) Kecakapan para pihak; (3) Hal tertentu; (4) Sebab yang halal.

Syarat kesepakatan (syarat pertama) dan syarat kecakapan para pihak (syarat kedua) sering disebut syarat subyektif, karena berkenaan dengan subyek perjanjian. Adapun syarat hal tertentu (syarat ketiga) dan sebab yang halal (syarat keempat) sering disebut sebagai syarat obyektif karena berkenaan dengan objek perjanjian. Pembedaan syarat sahnya perjanjian menjadi syarat subyektif dan syarat obyektif membawa perbedaan konsekuensi hukum jika kedua kelompok syarat tersebut tidak terpenuhi. Suatu perjanjian yang mengandung cacat pada subyeknya tidak menyebabkan perjanjian tersebut menjadi batal dengan sendirinya (nietig, batal demi hukum). Perjanjian yang tidak memenuhi syarat subyektif hanya memberikan kemungkinan untuk dibatalkan (vernietigbaar). Hal ini berbeda dengan syarat obyektif yang tidak terpenuhi menyebabkan perjanjian tersebut batal demi hukum (nietig).

Mertokusumo menyebut keempat syarat tersebut sebagai unsur essensialia dari sebuah perjanjian. Disebut demikian karena unsur essensialia ini mutlak harus ada bagi terjadinya sebuah perjanjian (Mertokusumo, 2010: 154). J. Satrio menyebutkan bahwa essensialia perjanjian adalah unsur perjanjian yang harus selalu ada dalam perjanjian, unsur mutlak, dimana tanpa adanya unsur tersebut perjanjian tak mungkin ada (J. Satrio, 1992: 57). Keharusan adanya unsur esensialia dalam sebuah perjanjian kiranya tidak lepas dari pentingnya keempat syarat tersebut, karena tanpa adanya keempat hal tersebut maka tidak akan pernah ada perjanjian.

Perjanjian lahir dengan telah tercapainya kata sepakat dari para pihak. Kesepakatan ini haruslah kesepakatan yang bulat, yang tidak mengandung unsur: paksaan, kesesatan, maupun penipuan, dan diberikan dalam suasana yang bebas tanpa tekanan apapun. Dalam perkembangannya kemudian, Hukum Perjanjian di Belanda menerima penyalahgunaan keadaan sebagai unsur yang menyebabkan dapat dibatalkannya perjanjian. Perkembangan ini memberikan perlindungan hukum bagi pihak yang dirugikan karena adanya paksaan tersebut.

\section{Unsur Penyalahgunaan Keadaan}

Saat ini, penyalah gunaan keadaan bukanlah hal baru dalam hukum perjanjian. Orang tak lagi menggugat perjanjian hanya karena terjadinya wanprestasi, namun juga karena penyalahgunaan keadaan. Hal ini juga telah disebut oleh J. Satrio (1992: 230-231), yang mengemukakan bahwa gejala "penyalahgunaan keadaan" sendiri bukanlah merupakan gejala baru. Adanya unsur seperti ini dalam perjanjian sudah dikenal sejak lama. Yang baru adalah bahwa ia diakui sebagai 
alasan tersendiri - di luar cacat dalam kehendak yang tradisional - untuk menuntut pembatalan perjanjian yang mengandung unsur seperti itu.

Dengan demikian dapat dikatakan bahwa ada perkembangan dalam cara pandang terhadap penyalahgunaan keadaan. Dahulu orang melihat penyalahgunaan keadaan sebagai suatu keadaan yang bertentangan dengan ketertiban umum atau kebiasaan yang baik (goede zeden), atau kesusilaan (J. Satrio, 1992: 231). Oleh karena itu orang menganggap gugatan penyalahgunaan keadaan berkaitan dengan syarat causa yang halal dalam sebuah perjanjian, dimana syarat causa yang halal adalah syarat objektif dalam perjanjian. Tidak dipenuhinya syarat objektif menyebabkan perjanjian batal demi hukum. Perjanjian yang batal demi hukum berarti bahwa perjanjian itu dianggap tidak pernah ada.

Dalam perkembangannya kemudian, orang memandang penyalahgunaan keadaan dari aspek kesepakatan. Karena kesepakatan merupakan syarat subyektif, maka tidak dipenuhinya syarat kesepakatan membawa konsekuensi bahwa perjanjian tersebut dapat dimintakan pembatalannya. Pembatalan tersebut bisa berupa pembatalan seluruh perjanjian ataupun pembatalan klausula tertentu yang dianggap tidak akan disetujui jika tidak terjadi cacat kehendak.

\section{Perkara Penyalahgunaan Keadaan dalam Praktik Pengadilan}

Dalam praktik pengadilan, cukup banyak perkara penyalahgunaan keadaan yang diajukan ke Pengadilan. Salah satu kasus yang diajukan di Pengadilan Negeri Semarang adalah kasus hutang piutang antara Pihak I (Kreditur-Tergugat) dengan pihak II (DebiturPenggugat).

\section{Kasus pertama:}

Persoalan berawal dari hutang piutang Debitur pada sebuah bank yang telah jatuh tempo, senilai Rp. 750.000.000,-. Agar jaminan hak tanggungan pada bank tersebut tidak dijual secara lelang, maka Debitur berusaha mencari pinjaman pada Kreditur senilai Rp. 750.000.000,- untuk melunasi hutangnya. Atas dasar hutang piutang yang baru tersebut, Kreditur meminta jaminan tanah yang dibebani dengan hak tanggungan oleh pihak bank. Sertifikat tanah tersebut kemudian dikuasai oleh Kreditur sebagai jaminan pelunasan hutang piutang dengan pihak Debitur. Terhadap jaminan tersebut Kreditur tidak melakukan pengikatan dengan Hak Tanggungan. Persoalan muncul karena dalam perjanjian hutang piutang tersebut diperjanjikan bahwa Kreditur secara otomatis berhak untuk memiliki tanah yang digunakan sebagai jaminan apabila Debitur wanprestasi.

Ketika hutang piutang antara Kreditur dan Debitur telah jatuh tempo, Debitur tidak mampu melunasi kewajibannya. Oleh karena itu pihak Kreditur mensomasi Debitur untuk melunasi kewajibnya. Debitur berupaya untuk mencari salinan perjanjian hutang piutang, karena Debitur tidak mendapatkan salinan perjanjian tersebut dari Notaris.

Setelah mendapatkan salinan perjanjian serta membaca dengan cermat, Debitur menyadari bahwa ia salah telah menyetujui sebuah perjanjian yang pada akhirnya merugikannya. Pihak Debitur kemudian mengajukan gugatan atas dasar penyalahgunaan keadaan oleh Kreditur.

\section{Kasus kedua:}

Kasus kedua adalah sebuah perjanjian yang dibuat oleh sepasang suami isteri. Perjanjian ini berawal ketika pihak isteri (Tergugat) menggugat cerai pada pihak suami. Pihak suami berupaya keras untuk mencegah agar perceraian tidak terjadi. Isteri bersedia membatalkan gugatan cerai tersebut dengan 
syarat si suami bersedia untuk menandatangani perjanjian pengasuhan anak dengan isterinya. Perjanjian dibuat oleh salah seorang Notaris di Kota Semarang.

Pasal 1 dalam perjanjian tersebut menyebutkan sebagai berikut:

(1) Pihak pertama (suami) tidak akan mengulangi kesalahan yang sama.

(2) Apabila pihak pertama mengulanginya, maka pihak kedua (isteri) akan menggugat cerai pihak pertama secara hukum dan pihak pertama harus menerima keputusan pihak kedua serta tidak akan melakukan perlawanan secara hukum sedangkan Hak Asuh Anak atas nama:

a. KGT, lahir di Semarang, pada tanggal 17 Agustus 2012, umur 4 tahun;

b. MKT, lahir di Semarang, pada tanggal 08 November 2013, umur 3 tahun;

menjadi hak asuh pihak kedua sepenuhnya.

Sejak penandatangan perjanjian, pihak suami menyadari sepenuhnya bahwa klausula tersebut sangat memberatkannya. Namun mengingat bahwa tujuan penandatanganan perjanjian tersebut adalah untuk mencegah agar isteri membatalkan gugatan cerai, maka suami menerima ketentuan tersebut.

Namun alam berkehendak lain. Dua tahun tiga bulan setelah penandatangan tersebut isteri kembali mengajukan gugat cerai kedua terhadap si suami, meskipun suami tidak melakukan kesalahan sebagaimana ketentuan pada Pasal 1 ayat (1) tersebut di atas. Menyadari bahwa ia kemungkinan akan kehilangan hak asuh atas anak-anaknya berdasarkan perjanjian tersebut, maka suami mengajukan gugatan untuk pembatalan perjanjian tersebut ke pengadilan negeri Kota Semarang dengan nomor: 437/Pdt.G/2018/PN Semarang. Salah satu pertimbangan yang diajukan oleh pihak suami (penggugat dalam gugatan pembatalan perjanjian pengasuhan anak) adalah "tidak ada kemauan yang bebas pada saat penandatanganan perjanjian tersebut."

Dari kedua perkara yang diajukan di Pengadilan Negeri Kota Semarang tampak bahwa pada dasarnya penggugat saat menandatangani perjanjian sadar bahwa perjanjian tersebut potensial merugikan dirinya, sehingga kesepakatan diberikan tidak dalam keadaan bebas sepenuhnya. Kesepakatan diberikan di bawah tekanan ekonomi (kasus pertama) maupun tekanan psikologis (kasus kedua).

\section{Unsur Penyalahgunaan Keadaan}

Pada dasarnya, kehendak sebagai dasar pembentuk kesepakatan dari para pihak haruslah kehendak yang murni, bebas, dan dinyatakan dengan suasana yang bebas pula. Namun ada kalanya, sepakat tidak tercapai dengan kehendak yang murni. Kehendaknya mungkin senagja diselewengkan ke arah lain atau diberikan dalam suasana yang tidak bebas. (J. Satrio, 1992: 187).

Dalam teori ilmu hukum, cacat kehendak adalah keadaan dimana seseorang terpaksa membuat perjanjian yang disebabkan suatu keadaan atau karena adanya penyalahgunaan keadaan oleh pihak lain. Artinya, bahwa ia tidak dalam keadaan bebas ketika menyampaikan pendapatnya. KUHPerdata telah mengatur bahwa terdapat tiga soal yang menyebabkan cacatnya kesepakatan, yakni dwang (paksaan), dwaling (kesesatan), dan bedrog (penipuan). Dalam perkembangannya, cacat kehendak juga dapat terjadi karena penyalahgunaan keadaan (misbruik van omstandigheden/undue invluence).

Dalam soal penyalahgunaan keadaan, menurut J. Satrio (2001: 317-318), terdapat beberapa faktor yang dapat dianggap sebagai ciri, yakni: 
a. Adanya keadaan ekonomis yang menekan, kesulitan keuangan yang mendesak;

b. Adanya hubungan atasan-bawahan; keunggulan ekonomis pada salah satu pihak, hubungan majikan-buruh; orangtua/wali- anak belum dewasa;

c. Adanya keadaan lain yang tidak menguntungkan, seperti pasien yang membutuhkan pertolongan dokter ahli;

d. Perjanjian tersebut mengandung hubungan yang timpang dalam kewajiban timbal balik antara para pihak (prestasi yang tak seimbang); seperti pembebasan majikan dari risiko dan menggesernya menjadi tanggungan buruh; atau

e. Kerugian yang sangat besar bagi salah satu pihak.

Pada kedua kasus tersebut di atas, terpenuhi unsur/ciri untuk dapat disebut telah terjadi penyalahgunaan keadaan.

Pada kasus pertama, keadaan ekonomi yang menekan menyebabkan Debitur bersedia menandatangani perjanjian meskipun terdapat klausula yang merugikan dirinya, yakni ketentuan bahwa tanah yang digunakan sebagai jaminan secara otomatis menjadi milik Kreditur apabila Debitur wanprestasi. Ketentuan ini bertentangan dengan Pasal 12 Undang-Undang Nomor 4 tahun 1996 tentang Hak Tanggungan (UUHT) yang menyebutkan: "Janji yang memberikan kewenangan pada pemegang Hak Tanggungan untuk memiliki obyek Hak Tanggungan apabila Debitor cidera janji, batal demi hukum". Dengan demikian, karena klausula tersebut bertentangan dengan ketentuan undang-undang, maka klausula tersebut tidak berlaku.

Berkaitan dengan soal kesepakatan, maka kesepakatan yang dibuat oleh para pihak menjadi kesepakatan yang cacat, karena kata sepakat diberikan tidak tidak dalam kondisi bebas. Hal inilah yang membuat Debitur tidak bisa memberikan kesepakatan secara bebas, sehingga tawaran hutang dengan klausula yang memberatkan pun diterima. Dalam kondisi terjepit dan ketidaktahuan akan norma hukum menyebabkan Debitur tidak berpikir panjang untuk memberikan kesepakatan.

Dalam kasus kedua, penyalahgunaan keadaan terjadi karena faktor psikologis yang menekan. Kreditur menghadapi kondisi yang tidak menguntungkan (sub c), karena dalam dilema antara mempertahankan perkawinan atau kehilangan hak asuh anak. Secara logika manusia pada umumnya, ketika perkawinan bertahan maka ia akan dapat mengasuh anakanaknya. Oleh karena alasan tersebutlah kiranya yang menyebabkan Penggugat bersedia menandatangani perjanjian yang sangat tidak menguntungkan baginya.

Berdasarkan alasan tersebut, kiranya layak jika hakim mengabulkan gugatan dari para Penggugat karena dalam kedua kasus tersebut terdapat unsur penyalahgunaan keadaan, yang menyebabkan penggugat memberikan kesepakatan dalam keadaan tidak bebas.

Di negara Inggris pun dikenal doktrin bahwa kesepakatan dalam perjanjian haruslah diberikan secara bebas dengan memahami secara penuh konsekuensi hukum yang timbul dari perjanjian tersebut. Hal ini sebagaimana Salmond menyebutkan bahwa "...freely and with full knowledge consented to it" (1947: 351). Dan "Essential error is that which is of such a nature as to prevent the existence of any real, consent, and therefore any real agreement" (1947: 357). Dengan demikian, tiadanya kebebasan menyatakan kehendak menjadi alasan bagi pihak yang dirugikan untuk mengajukan pembatalan perjanjian, dan pada sisi lain, hal tersebut menjadi pertimbangan bagi hakim untuk memberikan putusan seadil-adilnya bagi para pihak.

\section{Perbandingan pengaturan Penyalah- gunaan Keadaan di Belanda}


Di Indonesia, KUHPerdata hanya mengatur soal cacat kehendak dalam Pasal 1321 sampai dengan Pasal 1328 KUHPerdata. Pasal 1321 KUHPerdata menyebutkan: "Tiada sepakat yang sah apabila sepakat itu diberikan karena kekhilafan, atau diperolehnya dengan paksaan atau penipuan".

Penyalahgunaan keadaan merupakan hasil perkembangan dalam praktik peradilan yang dikembangkan menjadi doktrin. Hasanudin (http://PN-Tilamuta.go.id) menyebutkan bahwa penyalahgunaan keadaan dimulai dari Bovag Arrest III, yang diputuskan oleh Hoge Raad pada tanggal 26 Februari tahun 1965, dengan nomor NJ. 1965, 373. Dengan dikeluarkannya arrest tersebut maka hukum perjanjian di Negeri Belanda telah menerima penyalahgunaan keadaan sebagai alasan pembatalan perjanjian, baik untuk seluruhnya maupun untuk sebagian. Perkembangan ini kemudian diikuti di Indonesia, meskipun pada tahun 1965 Indonesia tidak lagi jajahan Belanda yang harus mengikuti perkembangan hukum di Belanda.

Di Belanda, perkembangan penggunaan unsur penyalahgunaan keadaan sebagai alasan pembatalan perjanjian berkembang pesat. Unsur ini dikenal sejak lama sebagai alasan pembatalan perjanjian, yang baru adalah bahwa ia diakui sebagai salah satu alasan tersendiri - di luar cacat kehendak yang tradisional - untuk menuntut pembatalan perjanjian yang mengandung unsur seperti itu. J. Satrio menyatakan bahwa semula unsur penyalahgunaan keadaan dianggap bertentangan dengan soal ketertiban umum atau dengan kebiasaan baik (goede zeden) atau moralitas, sehingga penyalahgunaan keadaan dikaitkan dengan unsur causa atau sebab diadakannya suatu perjanjian (1991: 231).

Suatu perjanjian yang mengandung unsur causa atau sebab atau tujuan yang tidak halal, membawa akibat hukum bahwa perjanjian tersebut batal demi hukum. Hal ini karena causa yang halal termasuk sebagai syarat obyektif. Tidak dipenuhinya syarat obyektif, atau syarat yang berkenaan dengan objek perjanjian menyebabkan perjanjian tersebut batal demi hukum. Pembatalan seluruh perjanjian, tidak selalu keadaan yang dikehendaki oleh hukum. Yang dikehendaki adalah bagian yang dipandang terjadi karena adanya unsur penyalahgunaan keadaan, maka bagian itu sajalah yang perlu diperbaiki.

Di Belanda saat ini, unsur penyalahgunaan keadaan telah diatur dalam Nieuw Burgerlijk Wetboek (NBW). NBW yang mulai berlaku pada tahun 1992 mengatur soal penyalahgunaan keadaan dalam Pasal 3: 44 ayat (4), yang menyebutkan empat syarat untuk adanya penyalahgunaan keadaan, yaitu:

a. Keadaan khusus, seperti keadaan yang mendesak, ketergantungan, kecerobohan, kondisi mental yang tidak normal atau ketiadaan pengalaman.

b. Pengetahuan. Ada syarat yang perlu bahwa pihak lain tahu atau semestinya mengetahui bahwa ada keadaan khusus yang memotivasi pihak pertama untuk menutup suatu perjanjian.

c. Penyalahgunaan. Pihak lain harus sudah mengusulkan pembentukan kontrak meskipun hal-hal yang dia tahu, atau seharusnya tahu, bisa membuat dia tidak dapat memiliki kontrak tersebut.

d. Kausalitas. Diperlukan syarat bahwa kontrak tidak akan terjadi jika tidak ada penyalahgunaan keadaan (Rosa Agustina, 2012: 142).

Syarat sebagaimana diatur dalam Pasal 3: 44 ayat (4) NBW tersebut bersifat kumulatif, artinya bahwa keempat syarat harus terpenuhi. Bandingkan hal ini dengan ketentuan Pasal 1365 KUHPerdata yang menghendaki bahwa perbuatan melawan 
hukum mengandung empat (4) unsur yang keempat-empatnya harus terpenuhi dan dapat dibuktikan. Ukuran ini menjadi ukuran yang terukur dan jelas.

Mengenai siapakah yang berhak mengajukan pembatalan perjanjian, mengacu pada ketentuan Pasal 1449 KUHPerdata yang memberikan kesempatan untuk membatalkan perjanjian pada pihak yang mengalami kekhilafan, paksaan, dan penipuan, maka berdasarkan interpretasi ekstensif terhadap ketentuan Pasal 1449 KUHPerdata, pihak yang mengalami penyalahgunaan keadaanlah yang berhak mengajukan pembatalan perjanjian, bukan kepada pihak yang curang.

Mengutip pandangan Isnaeni (2016: 140), kontraktan (penulis: pihak dalam kontrak) yang tidak memenuhi unsur subyektif, selayaknya kalau pihak itulah yang diberi kesempatan untuk meminta pembatalan perjanjian. Sedangkan mitranya tidak boleh meminta pembatalan agar supaya adil, juga untuk menghindari kemungkinan terjadinya kecurangan. Adapun jangka waktu daluwarsa hak mengajukan gugatan pembatalan perjanjian adalah lima (5) tahun. Hal ini dimaksudkan untuk memberikan kepastian hukum tentang bagaimana nasib sebuah perjanjian yang tidak memenuhi unsur subyektif.

Dalam sistem hukum Indonesia kiranya akan cukup sulit untuk mengatur perihal "penyalahgunaan keadaan" dalam perjanjian, karena sampai saat ini Indonesia belum memiliki undang-undang Nasional yang secara khusus mengatur mengenai perjanjian, sedangkan KUHPerdata hanya berlaku secara terbatas bagi mereka yang merupakan keturunan Eropa ataupun keturunan Timur Asing saja. Mengatur dalam sebuah norma hukum yang pasti akan menjamin kepastian hukum bagi para pihak, terutama pihak yang dirugikan, keadilan serta kemanfaatan.

\section{PENUTUP}

\section{Kesimpulan}

1. Kesepakatan, kecakapan para pihak, hal tertentu, dan causa yang halal merupakan unsur esensial perjanjian. Tanpa terpenuhi keempat syarat tersebut maka perjanjian tidak sah.

2. Kesepakatan harus diberikan secara bebas, tidak bercacat. Cacat kehendak terjadi karena: kesesatan, kekhilafan, penipuan, serta penyalahgunaan keadaan. Cacat kehendak memberikan hak kepada pihak yang mengalami penyalahgunaan keadaan untuk mengajukan pembatalan perjanjian baik batal keseluruhan maupun batal untuk bagian tertentu yang dianggap disepakati dalam tekanan.

3. Praktik peradilan pada umumnya telah menerima penyalahgunaan keadaan sebagai salah satu alasan pembatalan perjanjian.

4. Agar lebih memiliki kekuatan hukum, menjamin keadilan, kepastian dan kemanfaatan, perlu diatur dalam norma hukum positif.

\section{DAFTAR PUSTAKA}

Buku:

J. Satrio, 1992, Hukum Perjanjian, Citra Aditya Bakti, Bandung.

J. Satrio, 2001, Hukum Perikatan, Perikatan yang Lahir dari Perjanjian Buku I, PT. Citra Aditya Bakti, Bandung.

Marzuki, Peter Mahmud, 2006, Penelitian Hukum, Prenada Media Group, Jakarta.

Mertokusumo, Sudikno, 2010, Mengenal Hukum Suatu Pengantar, Universitas Atma Jaya, Yogyakarta.

Moch Isnaeni, 2013, Perkembangan Hukum Perdata di Indonesia, Laksbang Grafika, Yogyakarta.

Moch. Isnaeni, 2016, Pijar Pendar Hukum Perdata, Revika Petra Media, Surabaya 
Moch. Isnaeni, 2017, Selintas Pintas, Hukum Perikatan Bagian Umum, Revika Petra Media, Surabaya.

Rosa Agustina, Hans Nieuwenhuis, Jaap Hijma, Suharnoko, 2012, Hukum Perikatan (Law of Obligations), Pustaka Larasan, Denpasar, Bali.

Salmond, Sir, 1947, Jurisprudence, Cetakan kesepuluh, John Sweet and Maxwell Itd., London.

Suharnoko, 2004, Hukum Perjanjian Teori dan Analisa Kasus, Prenada Media, Jakarta.

\section{Konvensi Internasional dan Peraturan Perundang-Undangan \\ Undang-Undang Dasar Negara Republik Indonesia Tahun 1945.}

Kitab Undang-Undang Hukum Perdata.

\section{Jurnal dan Publikasi Ilmiah}

N. Ike Kusmiati, Undue Influence sebagai Faktor Penyebab Cacat Kehendak diluar KUHPerdata, dalam Upaya Mengisi Kekosongan Hukum, Jurnal Litigasi, Fakultas Hukum Universitas Pasundan, URL: http://ejournal. unpas.ac.id/index.php/litigasi, Vol 17 (1), 2016, 3256-3283, DOI: http://dx.doi.org/10.23969/ litigasi.v17i1.97.

Internet/Website

Pengadilan Negeri Tilamuta, Penyalahgunaan Keadaan sebagai Alasan Pembatalan Perjanjian, 3 Februari 2019; URL: http://pn-tilamuta.go.id/2016/05/18/ penyalahgunaan-keadaan-sebagaialasan-pembatalan-perjanjian/ 